\title{
Inhibition of bovine sperm-zona binding by bovine herpesvirus-1
}

\author{
S Tanghe ${ }^{1 *}$, G Vanroose ${ }^{1 *}$, A Van Soom ${ }^{1}$, L Duchateau $^{2}$, M T Ysebaert ${ }^{2}$, P Kerkhofs $^{3}$, E Thiry ${ }^{4}$, \\ $\mathrm{S}$ van Drunen Littel-van den Hurk ${ }^{5}, \mathrm{P}$ Van Oostveldt ${ }^{6}$ and $\mathrm{H} \mathrm{Nauwynck}^{7}$ \\ ${ }^{1}$ Departments of Reproduction, Obstetrics and Herd Health and ${ }^{2}$ Physiology, Biochemistry and Biometry, Faculty \\ of Veterinary Medicine, University of Ghent, Salisburylaan 133, 9820 Merelbeke, Belgium, ${ }^{3}$ Department of \\ Virology, Veterinary and Agrochemical Research Center, 1180 Brussels, Belgium, ${ }^{4}$ Veterinary Virology, Faculty \\ of Veterinary Medicine, University of Liege, 4000 Liege, Belgium, ${ }^{5}$ Vaccine and Infectious Disease Organization, \\ University of Saskatchewan, Saskatoon, Saskatchewan S7N 5E3, Canada, ${ }^{6}$ Department of Molecular \\ Biotechnology, Faculty of Agricultural and Applied Biological Sciences, University of Ghent, 9000 Ghent, \\ Belgium, 'Laboratory of Virology, Department of Virology, Parasitology and Immunology, Faculty of Veterinary \\ Medicine, University of Ghent, 9820 Merelbeke, Belgium
}

Correspondence should be addressed to A Van Soom; Email: ann.vansoom@UGent.be

*(S Tanghe and G Vanroose contributed equally to this work)

\begin{abstract}
The purpose of the present study was to identify a potential interference of bovine herpesvirus-1 (BoHV-1) with sperm-oocyte interactions during bovine in vitro fertilization. An inhibition of almost $70 \%$ of sperm-zona binding was observed when bovine cumulus-denuded oocytes were inseminated in the presence of $10^{7} 50 \%$ tissue culture infective dose $/ \mathrm{ml} \mathrm{BoHV}-1$. The inhibitory effect of BoHV-1 on sperm-zona binding was mediated by an interaction of the virus with spermatozoa, but not with oocytes. Treatment of spermatozoa with BoHV-1, however, did not affect sperm motility and acrosomal status. Antiserum against BoHV-1 prevented the virus-induced inhibition of sperm-zona binding, indicating that BoHV-1 itself affects the fertilization process. In order to investigate which BoHV-1 glycoprotein(s) are responsible for the virus-sperm interaction, BoHV-1 was treated with monoclonal antibodies against the viral glycoproteins $\mathrm{gB}, \mathrm{gC}, \mathrm{gD}$ and $\mathrm{gH}$ prior to insemination. Anti-gC completely prevented the inhibitory effect of BoHV-1 on sperm-zona binding, while anti-gD caused a reduction of this inhibition. Further evidence for the involvement of $\mathrm{gC}$ and $\mathrm{gD}$ in the virus-sperm interaction was provided by the fact that purified $\mathrm{gC}$ and $\mathrm{gD}$ decreased sperm-zona binding in a dose-dependent way with $\mathrm{gC}$ being more effective than $\mathrm{gD}$. These results indicated that BoHV-1 inhibits bovine sperm-zona binding by interacting with spermatozoa. The binding of BoHV-1 to a spermatozoon is mediated by the viral glycoproteins $\mathrm{gC}$ and $\mathrm{gD}$, and therefore seems to be comparable with the mechanisms of
\end{abstract} BoHV-1 attachment to its natural host cell.

Reproduction (2005) 130 251-259

\section{Introduction}

Mammalian fertilization involves a cascade of cell-cell interactions in which carbohydrate complexes play an important role. In cattle, D-mannose and N-acetyl-D-galactosamine have been shown to participate in sperm-zona binding and sperm-oocyte fusion respectively (Gougoulidis et al. 1999, Amari et al. 2001). Moreover, we have recently demonstrated that D-mannose, L-fucose, fucoidan, dextran sulfate, fibronectin and vitronectin interfere with bovine in vitro fertilization (IVF) by inhibiting sperm penetration (Tanghe et al. 2004b) and that the p-aminophenyl derivative of D-mannose has an inhibitory effect on bovine sperm penetration by specifically blocking sperm-oocyte fusion (Tanghe et al. 2004a).
Besides being involved in the fertilization process, glycoproteins are also essential elements in the entry process of herpesviruses into host cells (Spear \& Longnecker 2003). Bovine herpesvirus-1 (BoHV-1), a member of the genus Varicellovirus in the subfamily of the Alphaherpesvirinae, is an important pathogen in cattle and has at least ten envelope glycoproteins, designated gB, gC, gD, gE, gG, gH, gl, gK, gL and gM (Schwyzer \& Ackermann 1996), with $\mathrm{gE} / \mathrm{gl}$ and $\mathrm{gH} / \mathrm{gL}$ forming complexes (van Drunen Little-van den Hurk et al. 1996, Yoshitake et al. 1997). The three major glycoproteins gB, gC and gD are present in large amounts on the virus envelope and the plasma membrane of virus-infected cells, and have been implicated in virus entry (Liang et al. 1991, Li et al. 1995, 
Baranowski et al. 1996). The entry process of alphaherpesviruses consists of two steps: initial virus attachment and subsequent virus penetration involving membrane fusion. The initial attachment of BoHV-1 to permissive cells is mediated by an interaction of $\mathrm{gC}$ with the cellular glycosaminoglycan heparan sulfate (Liang et al. 1991, Okazaki et al. 1991, Li et al. 1995). Glycoprotein gB binds initially to heparan sulfate and then with high affinity to a nonheparan sulfate receptor, whereas gD only binds to a nonheparan sulfate component (Byrne et al. 1995, Li et al. 1995). The entry receptors for gD could be mannose-6phosphate receptors described in herpes simplex virus (HSV) (Brunetti et al. 1995) and/or the poliovirus receptorrelated protein 1, also called the herpesvirus entry mediator C (HveC), described in BoHV-1 (Geraghty et al. 1998, Campadelli-Fiume et al. 2000, Martinez \& Spear 2002). Furthermore, glycoproteins $\mathrm{gB}$ and $\mathrm{gD}$ have been shown to play essential roles in membrane fusion during penetration and in direct cell-to-cell spread of BoHV-1 (Tikoo et al. 1990, Liang et al. 1995, Miethke et al. 1995, Li et al. 1997). Several minor BoHV-1 glycoproteins, such as $\mathrm{gE}, \mathrm{gG}, \mathrm{gH}$ and $\mathrm{gM}$, are less abundant on the virus envelope, but are important for virus penetration and/or virus transmission by direct cell-to-cell spread (Baranowski et al. 1996, van Drunen Little-van den Hurk et al. 1996, Rebordosa et al. 1996, Meyer et al. 1998, Wu et al. 1998, Schroder \& Keil 1999, Nakamichi et al. 2002).

Besides being associated with reproductive failure, such as abortion and temporary infertility due to postular vulvovaginitis and balanoposthitis (Engels \& Ackermann 1996), BoHV-1 could also cause infertility by directly affecting the fertilization process. There are four possible pathways by which BoHV-1 can be present during sperm-oocyte interactions in the oviduct: by contaminated semen, follicular fluid, granulosa cells and oviductal cells. Semen is usually contaminated with BoHV-1 (10 $0^{5}$ to $10^{8.5} 50 \%$ tissue culture infective dose $\left(\mathrm{TCID}_{50}\right) / \mathrm{ml} \mathrm{BoHV-1}$ during the acute phase of natural infection) which replicates in the mucosa of the prepuce, the penis and occasionally the distal urethra. Therefore, the seminal plasma rather than the spermatozoa will contain the virus (van Oirschot 1995, Vogel et al. 2004). However, some studies have reported the association of BoHV-1 with spermatozoa (Elazhary et al. 1980, Van Engelenburg et al. 1993), which could represent a potential pathway for the infection of an oocyte during fertilization. Additionally, since BoHV-1 has been detected in follicular fluid ( $10^{2.6}$ to $10^{9.6} \mathrm{TCID}_{50} / \mathrm{ml}$ BoHV- 1$)$, granulosa cells $\left(10^{2.2}\right.$ to $\left.10^{6.1} \mathrm{TCID}_{50} / \mathrm{ml} \mathrm{BoHV}-1\right)$ and oviductal cells $\left(10^{2.6}\right.$ to $10^{5.1} \mathrm{TCID}_{50} / \mathrm{ml}$ BoHV-1) derived from experimentally infected animals (Bielanski \& Dubuc 1994), virus particles could also become associated with the oocyte before ovulation in the preovulatory follicle or after ovulation during its residence in the oviduct.

The hypothesis that BoHV-1 could directly affect the fertilization process is supported by the observation of a strong decrease in embryonic development rate when bovine IVF was performed in the presence of BoHV-1
(Vanroose et al. 1999). These results and the fact that both mammalian fertilization and herpesvirus entry are carbohydrate-mediated processes suggest that BoHV-1 can interfere with bovine IVF by inhibiting sperm-oocyte interactions. Therefore, the present study was conducted to assess whether BoHV-1 has an adverse effect on bovine IVF and, if so, to investigate the underlying mechanisms.

\section{Materials and Methods \\ Media}

Unless otherwise noted, all chemicals and media were purchased from Sigma-Aldrich (Bornem, Belgium) and Invitrogen Life Technologies (Merelbeke, Belgium). A modified HEPES-buffered Tyrode balanced salt solution, termed HEPES-TALP, consisted of $3.1 \mathrm{mM} \mathrm{KCl}, 114 \mathrm{mM}$ $\mathrm{NaCl}, 2 \mathrm{mM} \mathrm{NaHCO}, 0.3 \mathrm{mM} \mathrm{NaH}{ }_{2} \mathrm{PO}_{4}, 2.1 \mathrm{mM} \mathrm{CaCl}$, $0.4 \mathrm{mM} \mathrm{MgCl}, 10 \mathrm{mM}$ sodium lactate, $0.2 \mathrm{mM}$ sodium pyruvate, $10 \mu \mathrm{g} / \mathrm{ml}$ gentamicin sulfate, $10 \mathrm{mM}$ HEPES and $3 \mathrm{mg} / \mathrm{ml}$ bovine serum albumin (BSA). Maturation medium contained modified bicarbonate-buffered Tissue Culture Medium-199 medium supplemented with 20\% heat-inactivated fetal calf serum (FCS; N.V. HyClone Europe S.A., Erembodegem, Belgium), $0.2 \mathrm{mM}$ sodium pyruvate, $50 \mu \mathrm{g} / \mathrm{ml}$ gentamicin sulfate and $0.4 \mathrm{mM}$ glutamine. Fertilization medium consisted of Tyrode balanced salt solution supplemented with $25 \mathrm{mM} \mathrm{NaHCO}_{3}, 10 \mathrm{mM}$ sodium lactate, $0.2 \mathrm{mM}$ sodium pyruvate, $10 \mu \mathrm{g} / \mathrm{ml}$ gentamicin sulfate, $6 \mathrm{mg} / \mathrm{ml}$ fatty acid-free BSA and $10 \mu \mathrm{g} / \mathrm{ml}$ heparin. Sperm-TALP contained Tyrode balanced salt solution supplemented with $25 \mathrm{mM} \mathrm{NaHCO}_{3}, 10 \mathrm{mM}$ sodium lactate, $0.2 \mathrm{mM}$ sodium pyruvate, $10 \mu \mathrm{g} / \mathrm{ml}$ gentamicin sulfate and $10 \mathrm{mM}$ HEPES.

\section{Oocyte collection and in vitro maturation}

Immature cumulus-oocyte complexes (COCs) were aspirated from follicles with a diameter of $2-6 \mathrm{~mm}$ from abattoir-collected ovaries and graded according to cytoplasmic homogeneity and uniform cumulus covering. After being washed in HEPES-TALP, the COCs were cultured in $500 \mu \mathrm{l}$ maturation medium for $24 \mathrm{~h}$ at $38.5^{\circ} \mathrm{C}$ in a humidified $5 \% \mathrm{CO}_{2}$ incubator.

\section{Sperm preparation}

For all experiments, frozen semen from the same bull was thawed by immersion for $30-60 \mathrm{~s}$ in a water bath at $37^{\circ} \mathrm{C}$. Live spermatozoa were selected by centrifugation (30 min at $900 \mathrm{~g}$ ) on a discontinuous Percoll (Pharmacia, Uppsala, Sweden) gradient composed of $2 \mathrm{ml} 90 \%$ and $2 \mathrm{ml} \mathrm{45 \%} \mathrm{Percoll} \mathrm{solutions} \mathrm{in} \mathrm{sperm-TALP.}$

\section{Fixation and staining of oocytes}

Oocytes were fixed for at least $24 \mathrm{~h}$ in $2 \%$ paraformaldehyde and $2 \%$ glutaraldehyde in phosphate-buffered saline 
(PBS) without calcium and magnesium, and stained for $10 \mathrm{~min}$ with $10 \mu \mathrm{g} / \mathrm{ml}$ Hoechst 33342 (Molecular Probes, Leiden, The Netherlands). The oocytes were mounted in $100 \%$ glycerol and nuclear material or blue fluorescing attached sperm nuclei were evaluated by means of a Leica DMR fluorescence microscope (Van Hopplynus N.V., Brussels, Belgium).

\section{Virus}

The BoHV-1 Cooper (Colorado) strain was obtained from the Veterinary and Agrochemical Research Center (Brussels, Belgium) and propagated in Madin-Darby bovine kidney cells grown in minimum essential medium supplemented with $10 \%$ FCS. The virus stocks had a titer of $10^{7.7}$ or $10^{8} \mathrm{TCID}_{50} / \mathrm{ml}$, and were stored frozen at $-70^{\circ} \mathrm{C}$ before use.

\section{Antisera against BoHV-1}

Sera from three calves collected before and 4 weeks after BoHV-1 inoculation were kindly provided by G Meyer (Veterinary Virology, Faculty of Veterinary Medicine, University of Liege, Belgium). The seroneutralization titers of all presera were $<2$ and of the postsera they were 2560, 1810 and 1522 respectively.

\section{Monoclonal antibodies against BoHV-1 glycoproteins}

Monoclonal antibodies (MAbs) against BoHV-1 glycoproteins were kindly provided by G Meyer (Dubuisson et al. 1992). Four neutralizing MAbs were used: anti-gB, anti-gC, anti-gD and anti-gH. The production and characterization of these MAbs have been described by Marshall et al. $(1986,1988)$.

\section{Purified BoHV-1 glycoproteins gB, gC and gD}

Purified BoHV-1 glycoproteins gB, gC and gD were provided by $S$ van Drunen Littel-van den Hurk. Affinity purification of $\mathrm{gB}, \mathrm{gC}$ and $\mathrm{gD}$ from virus-infected cells was carried out as previously described (van Drunen Littel-van den Hurk \& Babiuk 1985).

\section{Experimental design}

Experiment 1: effect of BoHV-1 on sperm-zona binding

In vitro matured COCs were mechanically denuded and assigned randomly to four different media: fertilization medium supplemented with 0 (control), $10^{5}, 10^{6}$ and $10^{7}$ $\mathrm{TCID}_{50} / \mathrm{ml}$ BoHV-1 (three independent replicates). One hundred cumulus-denuded oocytes (CDOs) of each experimental group were coincubated with sperm at a final concentration of $10^{5}$ spermatozoa $/ \mathrm{ml}$ in $500 \mu \mathrm{l}$ fertilization medium at $38.5^{\circ} \mathrm{C}$ in a humidified $5 \% \mathrm{CO}_{2}$ incubator. At $24 \mathrm{~h}$ post insemination (hpi), 20 oocytes were collected from each group, washed three times in
HEPES-TALP, fixed and stained. The number of spermatozoa bound to the zona pellucida was determined.

Experiment 2: interaction of BoHV-1 with spermatozoon or oocyte

In vitro matured COCs were mechanically denuded and divided randomly into three different groups (three independent replicates). Group 1 (control) was inseminated under standard conditions. In group 2, CDOs were preincubated with $10^{7} \mathrm{TCID}_{50} / \mathrm{ml} \mathrm{BoHV}-1$ for $2 \mathrm{~h}$ at $38.5^{\circ} \mathrm{C}$. After preincubation, the oocytes were washed three times in HEPES-TALP and used for IVF. In group 3, $10^{5}$ spermato$\mathrm{zoa} / \mathrm{ml}$ were preincubated with $10^{7} \mathrm{TCID}_{50} / \mathrm{ml} \mathrm{BoHV}-1$ for $2 \mathrm{~h}$ at $38.5^{\circ} \mathrm{C}$. After preincubation, the sperm suspension was washed twice with HEPES-TALP by means of centrifugation $(10 \mathrm{~min}$ at $500 \mathrm{~g})$ and used for IVF. The CDOs of each experimental group were coincubated with sperm at a final concentration of $10^{5}$ spermatozoa $/ \mathrm{ml}$ in $50 \mu \mathrm{l}$ droplets of medium (ten oocytes/droplet) overlaid with paraffin oil (Merck-Belgolabo, Overijse, Belgium). At 0.5, 3, 6 and $24 \mathrm{hpi}, 20$ oocytes were collected from each group, washed three times in HEPES-TALP, fixed and stained. The number of spermatozoa bound to the zona pellucida was determined.

Experiment 3: effect of BoHV-1 on sperm motility and acrosome reaction

After Percoll centrifugation, the sperm pellet was resuspended in sperm-TALP supplemented with $6 \mathrm{mg} / \mathrm{ml}$ BSA and $10 \mu \mathrm{g} / \mathrm{ml}$ heparin $\left(40 \times 10^{6}\right.$ spermatozoa $\left./ \mathrm{ml}\right)$, and incubated for $30 \mathrm{~min}$ at $38.5^{\circ} \mathrm{C}$ to induce capacitation (three independent replicates) (Gordon 1994). Subsequently, the sperm suspension was divided into five aliquots. Aliquot 1 was supplemented with $10 \mu \mathrm{M}$ A23187 calcium ionophore as full response control and aliquot 2 was used as negative control. Aliquots 3,4 and 5 were supplemented with $10^{5}, 10^{6}$ and $10^{7} \mathrm{TCID}_{50} / \mathrm{ml}$ BoHV-1 respectively. The sperm aliquots were incubated at $38.5^{\circ} \mathrm{C}$.

At $0,1,3$ and $5 \mathrm{~h}$ post incubation, total and progressive motility of sperm aliquots $2-5$ were evaluated objectively by using the Hamilton Thorne computer-assisted sperm analyzer (HTR Ceros 12.1; Orange Medical, Brussels, Belgium). Five microliters of each sperm aliquot was inserted into a Leja counting chamber (Nieuw-Vennep, The Netherlands) at $37^{\circ} \mathrm{C}$. Five randomly selected microscopic fields were scanned five times each. The mean of the five scans for each microscopic field was used for statistical analysis. The instrument settings for the HTR Ceros 12.1 were 30 frames at a frame rate of 60 frames/s, minimum contrast of 20, minimum cell size of 5 pixels, cells were considered to be progressive if velocity average pathway (VAP) $>50 \mu \mathrm{m} / \mathrm{s}$ and straightness $>70 \%$. Spermatozoa with a VAP of more than $30 \mu \mathrm{m} / \mathrm{s}$ were considered as motile.

At $1 \mathrm{~h}$ post incubation, the acrosomal status of sperm aliquots 1-5 was determined using fluorescein isothiocyanate-conjugated pisum sativum agglutinin 
(PSA-FITC). After centrifuging the sperm aliquots $(10 \mathrm{~min}$ at $720 \mathrm{~g}$ ), the supernatant was removed and the sperm pellets were resuspended in $50 \mu \mathrm{l}$ absolute ethyl alcohol (VWR, Haasrode, Belgium). After an incubation period of $30 \mathrm{~min}$ at $4^{\circ} \mathrm{C}, 15 \mu \mathrm{l}$ of each sperm aliquot was smeared on a glass slide, air-dried and $15 \mu$ I PSA-FITC (2 mg PSAFITC diluted in $2 \mathrm{ml}$ PBS) was added. The glass slides were kept for $15 \mathrm{~min}$ at $4{ }^{\circ} \mathrm{C}$, washed 15 times with aqua bidest and air-dried. At least 300 spermatozoa in each sperm aliquot were examined. The acrosomal region of acrosome-intact spermatozoa was labeled green, while acrosome-reacted spermatozoa retained only an equatorial labeled band with little or no labeling of the anterior head region (Kawakami et al. 1993).

\section{Experiment 4: effect of antisera against BoHV-1 on sperm-zona binding}

In vitro matured COCs were mechanically denuded and divided randomly into four different groups (three independent replicates). Group 1 (negative control) was inseminated under standard conditions. In group 2 (positive control), CDOs were inseminated with sperm preincubated with $10^{7} \mathrm{TCID}_{50} / \mathrm{ml} \mathrm{BoHV}-1$ for $2 \mathrm{~h}$ at $38.5^{\circ} \mathrm{C}$. Groups 3 and 4 were inseminated in the presence of $10^{7} \mathrm{TCID}_{50} / \mathrm{ml}$ BoHV-1 preincubated with an equal volume of tenfold dilutions of, respectively, preserum and postserum against BoHV-1 $(1: 4,1: 40,1: 400,1: 4000)$ for $2 \mathrm{~h}$ at $37^{\circ} \mathrm{C}$. Preserum and postserum were diluted in fertilization medium. The CDOs of each experimental group were coincubated with sperm at a final concentration of $10^{5}$ spermatozoa $/ \mathrm{ml}$ in $50 \mu \mathrm{l}$ droplets of medium (ten oocytes/droplet) overlaid with paraffin oil. At $24 \mathrm{hpi}, 20$ oocytes were collected from each group, washed three times in HEPES-TALP, fixed and stained. The number of spermatozoa bound to the zona pellucida was determined.

\section{Experiment 5: effect of monoclonal antibodies against} BoHV-1 glycoproteins on sperm-zona binding

In vitro matured COCs were mechanically denuded and divided randomly into six different groups (three independent replicates). Group 1 (negative control) was inseminated under standard conditions. In group 2 (positive control), CDOs were inseminated with sperm preincubated with $10^{7} \mathrm{TCID}_{50} / \mathrm{ml} \mathrm{BoHV}-1$ for $2 \mathrm{~h}$ at $38.5^{\circ} \mathrm{C}$. Groups $3-6$ were inseminated in the presence of $10^{7} \mathrm{TCID}_{50} / \mathrm{ml}$ BoHV1 preincubated with an equal volume of fivefold dilutions of the respective MAbs against the BoHV-1 glycoproteins $\mathrm{gB}, \mathrm{gC}, \mathrm{gD}$ and $\mathrm{gH}(1: 5,1: 25,1: 125,1: 625)$ for $2 \mathrm{~h}$ at $37^{\circ} \mathrm{C}$. Monoclonal antibodies were diluted in fertilization medium. The CDOs of each experimental group were coincubated with sperm at a final concentration of $10^{5}$ spermatozoa $/ \mathrm{ml}$ in $50 \mu \mathrm{l}$ droplets of medium (ten oocytes/droplet) overlaid with paraffin oil. At $24 \mathrm{hpi}, 20$ oocytes were collected from each group, washed three times in HEPES-TALP, fixed and stained. The number of spermatozoa bound to the zona pellucida was determined.
Experiment 6: effect of purified BoHV-1 glycoproteins on sperm-zona binding

In vitro matured COCs were mechanically denuded and assigned randomly to five different media: fertilization medium supplemented with 0 (control), 0.001, 0.01, 0.1 and $1 \mu \mathrm{g} / \mathrm{ml}$ of the purified BoHV-1 glycoproteins gB, gC, $\mathrm{gD}$ or $\mathrm{gH}$ (three independent replicates). The CDOs of each experimental group were coincubated with sperm at a final concentration of $10^{5}$ spermatozoa $/ \mathrm{ml}$ in $50 \mu \mathrm{l}$ droplets of medium (ten oocytes/droplet) overlaid with paraffin oil. At $24 \mathrm{hpi}, 20$ oocytes were collected from each group, washed three times in HEPES-TALP, fixed and stained. The number of spermatozoa bound to the zona pellucida was determined.

Experiment 7: localization of streptavidin-fluorescein isothiocyanate-conjugated biotinylated $\mathrm{BoHV}-1$ on spermatozoa

Purified BoHV-1 was biotinylated using the instructions of the manufacturer (ECL protein biotinylation kit; Amersham International plc, Amersham, Bucks, UK). After biotinylation, $10^{6}$ spermatozoa $/ \mathrm{ml}$ were incubated with $10^{8}$ $\mathrm{TCID}_{50} / \mathrm{ml}$ biotinylated BoHV-1 for $1 \mathrm{~h}$ at $38.5^{\circ} \mathrm{C}$. After five washings, fluorescein isothiocyanate-conjugated streptavidin (streptavidin-FITC) was added. The localization of BoHV-1 on spermatozoa was demonstrated visually by using a Bio-Rad MRC 1024 Laser Scanning Confocal Microscope (Bio-Rad, Hemel-Hempstead, Herts, UK) linked to a Nikon Diaphot 300 microscope (Nikon Corp., Tokyo, Japan) and interfaced to a Compaq Prosignia 300 (Compaq Computer Corp., Houston TX, USA).

\section{Statistical analysis}

Differences in the number of spermatozoa bound to the zona pellucida, in total and progressive sperm motility and in acrosomal status were analyzed using mixed models with (calf sera within) replicate as random effect (MIXED procedure; SAS 9.1; Cary, NC, USA). Virus concentration (experiment 1), insemination time, group and their interaction (experiment 2), incubation time, group and their interaction (experiment 3), experimental group (experiments 4 and 5) and BoHV-1 glycoprotein concentration (experiment 6) were considered as categorical fixed effects. In experiment 3, BoHV-1 concentration was used as continuous fixed effect. Variation is expressed as S.E.M. Hypothesis testing was performed using a global significance level of $5 \%$. Pairwise comparisons of all groups were carried out using Tukey's multiple comparisons adjustment technique.

\section{Results}

\section{Experiment 1: effect of BoHV-1 on sperm-zona binding}

The mean number of bound spermatozoa in the presence of 0 (control), $10^{5}, 10^{6}$ and $10^{7} \mathrm{TCID}_{50}$ BoHV- $1 / \mathrm{ml}$ was 
198, 188, 96 and 62 respectively (Fig. 1). BoHV-1 significantly decreased sperm-zona binding at all concentrations tested $(P<0.0001)$. The decrease was more pronounced as the BoHV-1 concentration increased. At a concentration of $10^{7} \mathrm{TCID}_{50}$ BoHV-1/ml, sperm-zona binding was inhibited with $69 \%$.

\section{Experiment 2: interaction of BoHV-1 with spermatozoon or oocyte}

At 3, 6 and $24 \mathrm{hpi}$, sperm-zona binding in group 3 (sperm preincubated with BoHV-1) was significantly lower than that in group 1 (control) $(P<0.0001$; Fig. 2). At 0.5, 6 and $24 \mathrm{hpi}$, there was no significant difference in the number of bound spermatozoa between the control and group 2 (oocytes preincubated with BoHV-1).

\section{Experiment 3: effect of BoHV-1 on sperm motility and acrosome reaction}

At all incubation times, both total and progressive motility were not negatively influenced by the different BoHV-1 concentrations (data not shown).

In medium without supplements (negative control) and in medium supplemented with the calcium ionophore (full response control), respectively $15 \pm 3 \%$ (means \pm S.E.M.) and $68 \pm 3 \%$ of the spermatozoa underwent the acrosome reaction. Adding increasing BoHV-1 concentrations to the medium did not significantly influence the sperm acrosomal status compared with the negative control (data not shown).

\section{Experiment 4: effect of antisera against BoHV-1 on sperm-zona binding}

Inseminating CDOs with sperm preincubated with BoHV-1 (positive control) significantly inhibited sperm-zona binding compared with CDOs inseminated under standard conditions (negative control) (53\% inhibition; $P<0.0001$; Fig. 3). Preincubating BoHV-1 with different dilutions of preserum (1:40 to 1:4000) and with the 1:4000 dilution of postserum caused a similar inhibition of sperm-zona binding as the positive control. However, BoHV-1 preincubated

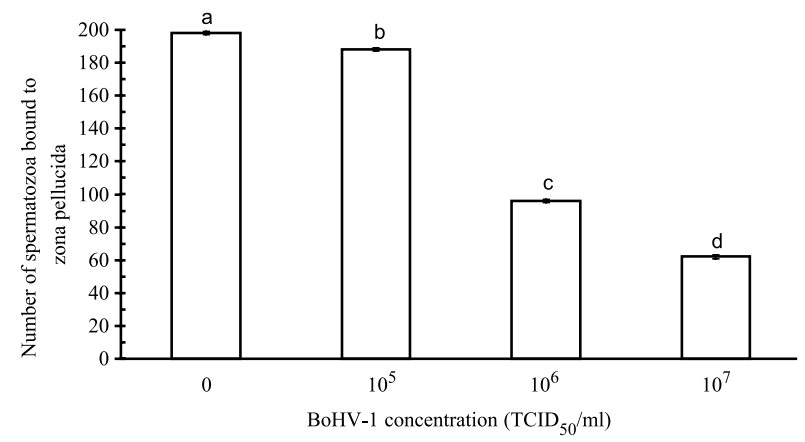

Figure 1 Number of spermatozoa bound to the zona pellucida of oocytes inseminated in fertilization medium supplemented with 0 , $10^{5}, 10^{6}$ and $10^{7} \mathrm{TCID}_{50}$ BoHV- $1 / \mathrm{ml}$. Concentrations with different letters are significantly different $(P<0.05)$.

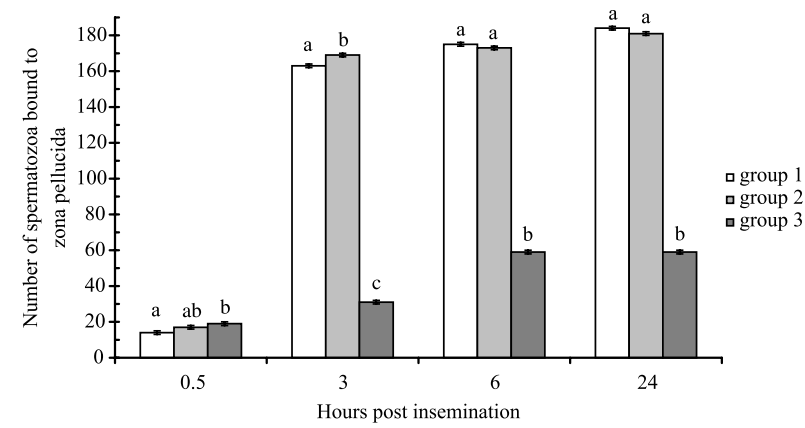

Figure 2 Number of spermatozoa bound to the zona pellucida of oocytes inseminated under standard conditions (group 1), of oocytes preincubated with BoHV-1 prior to insemination (group 2) and of oocytes inseminated with sperm preincubated with BoHV-1 (group 3) as a function of the insemination time. Treatment groups at a particular incubation time with different letters are significantly different $(P<0.05)$

with the 1:4, 1:40 and 1:400 dilutions of postserum significantly prevented the virus-induced inhibition of spermzona binding $(P<0.0001)$. Inseminating CDOs in the presence of BoHV-1 preincubated with the 1:4 dilution of postserum even resulted in a sperm-zona binding number which did not differ significantly from that of the negative control.

\section{Experiment 5: effect of monoclonal antibodies against BoHV-1 glycoproteins on sperm-zona binding}

Inseminating CDOs with sperm preincubated with BoHV-1 (positive control) significantly inhibited sperm-zona binding compared with CDOs inseminated under standard conditions (negative control) $(P<0.0001$; Fig. 4). BoHV-1 preincubated with the $1: 5$ and $1: 25$ dilutions of anti-gC and with the 1:5 dilution of anti-gD significantly prevented the virus-induced inhibition of sperm-zona binding $(P<0.0001)$. Inseminating CDOs in the presence of BoHV-1 preincubated with the 1:5 dilution of anti-gC

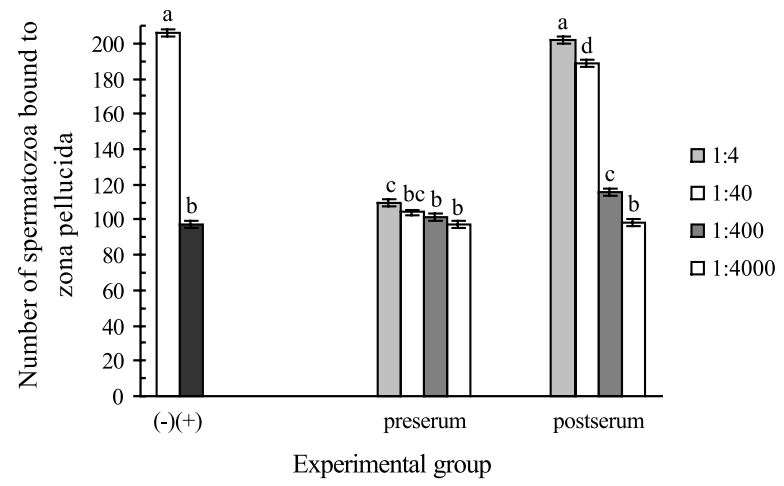

Figure 3 Number of spermatozoa bound to the zona pellucida of oocytes inseminated under standard conditions $(-)$, of oocytes inseminated with sperm preincubated with BoHV-1 (+) and of oocytes inseminated in the presence of BoHV-1 preincubated with 1:4, 1:40, 1:400 and 1:4000 dilutions of preserum and postserum. Treatment groups with different letters are significantly different $(P<0.05)$. 
even resulted in a sperm-zona binding number which did not differ significantly from that of the negative control. The 1:5, 1:25 and 1:125 dilutions of $\mathrm{gB}$ and the 1:25 dilution of $\mathrm{gD}$ also caused a significant but slight increase in sperm-zona binding compared with the positive control $(P<0.05)$. Sperm-zona binding in the presence of all the other dilutions of anti-gB, anti-gC, anti-gD and anti-gH was not significantly different from that of the positive control.

\section{Experiment 6: effect of purified BoHV-1 glycoproteins on sperm-zona binding}

Among the purified BoHV-1 glycoproteins tested, gC produced the largest inhibitory effect on sperm-zona binding (Fig. 5). Glycoprotein gC significantly decreased spermzona binding at all concentrations tested $(P<0.001)$, whereas gD significantly inhibited sperm-zona binding at a concentration of $0.01,0.1$ and $1 \mu \mathrm{g} / \mathrm{ml}(P<0.0001)$. For both $\mathrm{gC}$ and $\mathrm{gD}$, the decrease was more pronounced as the glycoprotein concentration increased. Glycoprotein gB only caused a significant decrease in sperm-zona binding at $1 \mu \mathrm{g} / \mathrm{ml}(P<0.001)$.

\section{Experiment 7: localization of streptavidin-FITC- conjugated biotinylated BoHV-1 on spermatozoa}

Bovine spermatozoa were processed for laser scanning confocal microscopy to assess the location of the specific binding sites of BoHV-1 (Fig. 6). In acrosome-intact sperm, green fluorescence was observed at the entire postacrosomal region as well as at some parts of the acrosomal cap and tail. In acrosome-reacted sperm, BoHV-1 binding was limited to the equatorial head region.

\section{Discussion}

Previous research in our laboratory has demonstrated that the exposure of in vitro matured bovine COCs to $10^{6.7}$ $\mathrm{TCID}_{50} / \mathrm{ml}$ BoHV-1 during IVF causes an inhibition of the cleavage rate, the percentage of eight-cell stage embryos

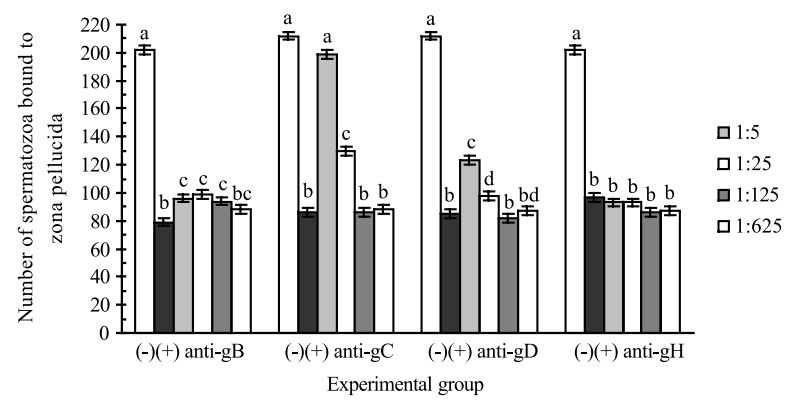

Figure 4 Number of spermatozoa bound to the zona pellucida of oocytes inseminated under standard conditions (-), of oocytes inseminated with sperm preincubated with BoHV-1 (+) and of oocytes inseminated in the presence of BoHV-1 preincubated with 1:5, 1:25, 1:125 and 1:625 dilutions of monoclonal antibodies against gB, gC, $\mathrm{gD}$ and $\mathrm{gH}$. Concentrations within a particular monoclonal antibody group with different letters are significantly different $(P<0.05)$.

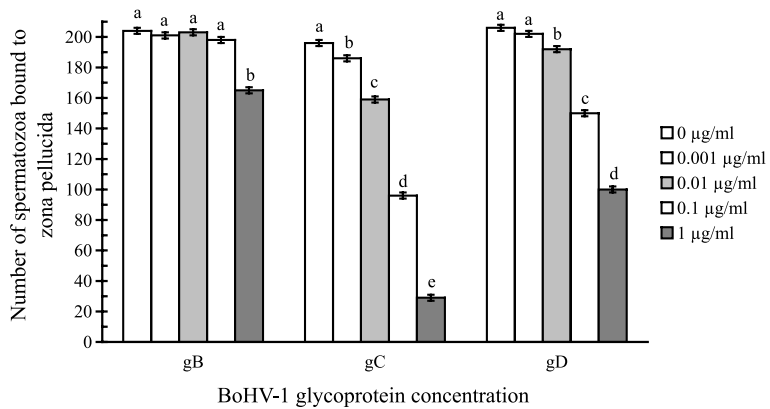

Figure 5 Number of spermatozoa bound to the zona pellucida of oocytes inseminated in fertilization medium supplemented with 0 , $0.001,0.01,0.1$ or $1 \mu \mathrm{g} / \mathrm{ml} \mathrm{gB} \mathrm{(S.E.M.} \mathrm{=} \mathrm{3),} \mathrm{gC} \mathrm{(S.E.M.}=2$ ) or $\mathrm{gD}$ $($ S.E.M. $=2)$. Concentrations within a particular glycoprotein group with different letters are significantly different $(P<0.05)$.

and the blastocyst rate of 50\%, 91\% and $94 \%$ respectively (Vanroose et al. 1999). This inhibitory effect was not due to virus replication in the embryonic cells, since an intact zona pellucida acts as a protective barrier against BoHV-1 (Vanroose et al. 1997, 1998). Therefore, other reasons need to be established to explain the adverse effect of BoHV-1 on embryonic development. Preliminary experiments showed that coincubating bovine CDOs with $10^{6}$ and $10^{5}$ spermatozoa $/ \mathrm{ml}$ in the presence of $10^{7} \mathrm{TCID}_{50} / \mathrm{ml} \mathrm{BoHV}-1$ inhibited the fertilization rate with 50\% (BoHV-1:sperm ratio of $10: 1$ ) and $75 \%$ (BoHV-1:sperm ratio of 100:1) respectively (G Vanroose, unpublished observations). The results presented in this study demonstrated that in the presence of a BoHV-1:sperm ratio of 100:1 sperm-zona binding was inhibited with $69 \%$. Therefore, the virus-induced inhibition of the fertilization rate is mainly caused by reduced sperm binding to the zona pellucida.

In order to investigate whether BoHV-1 has a preference for interacting with spermatozoa or oocytes, both gametes were incubated separately with the virus prior to bovine IVF. Inhibition of sperm-zona binding was observed when spermatozoa were preincubated with BoHV-1, whereas oocyte preincubation with BoHV-1 did not affect sperm-zona binding. These observations indicated that BoHV-1 interacts with the spermatozoon and were confirmed by the fact that streptavidin-FITC-conjugated biotinylated BoHV-1 particles could be localized on the head of acrosome-intact bovine spermatozoa by means of laser scanning confocal microscopy (Fig. 6). Furthermore, the localization of virions on the equatorial head region of acrosome-reacted bovine spermatozoa suggested that BoHV-1 cannot only interfere with sperm-zona binding but also with subsequent fertilization steps, such as sperm-oolemma binding and sperm-oocyte fusion.

The virus-induced inhibition of sperm-zona binding may be due to a toxic effect of BoHV-1 on sperm characteristics related to the sperm's ability to bind to the zona pellucida, such as sperm capacitation, motility and acrosome reaction. Since the BoHV-1 glycoprotein gC functions as a major virus attachment protein through binding to a heparin-like moiety on host cells (Okazaki et al. 

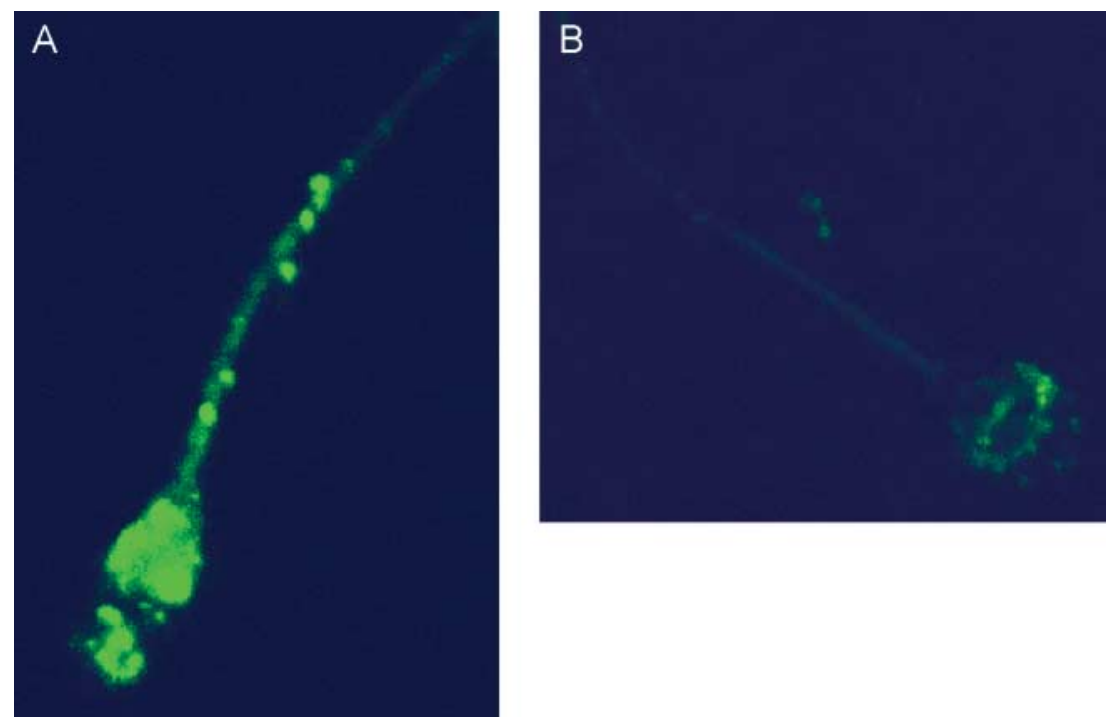

Figure 6 Laser scanning confocal photomicrographs of biotinylated BoHV-1 visualized with streptavidin-FITC on (A) acrosome-intact and (B) acrosome-reacted bovine sperm (magnification $\times 2500)$.
1994), the observed inhibitory effect may be caused by an interaction of BoHV-1 particles with heparin present in the fertilization medium. Regarding the in vitro use of heparin as a capacitating agent of bovine sperm (Parrish et al. 1988), the decrease of functionally active heparin in the medium could lead to disturbed sperm capacitation. However, this seems to be an unlikely situation, since the same inhibition of sperm-zona binding was observed with non-heparinized spermatozoa as with heparinized spermatozoa (G Vanroose, unpublished observations). Further evidence for a non-toxic effect of BoHV-1 on sperm was provided by the fact that both sperm motility (total and progressive) and acrosomal status were not affected by BoHV-1. A decreased sperm motility in semen obtained from diseased bulls was observed, but was attributed to the general illness rather than to a direct effect of BoHV-1 on spermatozoa (Huck et al. 1971).

Indications were found that BoHV-1 itself affects the IVF process, since treatment of the virus with the highest tested concentration of postserum against BoHV-1 prior to insemination completely prevented its inhibitory effect on sperm-zona binding. In order to investigate which BoHV1 glycoprotein(s) are responsible for the virus-sperm interaction, BoHV-1 was preincubated with MAbs against the BoHV-1 glycoproteins $\mathrm{gB}, \mathrm{gC}, \mathrm{gD}$ and $\mathrm{gH}$. The highest tested concentration of anti-gC completely prevented the virus-induced inhibition of sperm-zona binding, while anti-gD at the same concentration partly prevented the inhibitory effect of BoHV-1. Anti-gB and anti-gH had little or no influence on sperm-zona binding in the presence of BoHV-1. Further evidence for the involvement of $\mathrm{gC}$ and $\mathrm{gD}$ in the virus-sperm interaction was provided by the fact that both purified gC and gD inhibited sperm-zona binding in a dose-dependent way. The inhibitory effect of gD, however, was less pronounced. These results are consistent with studies reporting that the initial attachment of alphaherpesviruses to permissive cells is mediated by an interaction of gC with the cellular glycosaminoglycan heparan sulfate, followed by an interaction of gD with other cellular receptors (Fuller \& Lee 1992, Lee \& Fuller 1993, McClain \& Fuller 1994, Li et al. 1995). Furthermore, Liang et al. (1991) described that the gC-dependent attachment becomes a more stable binding by the interaction of $\mathrm{gD}$ with its receptor. Based on our results, gB appears not to be involved in the initial attachment of BoHV-1 particles to a spermatozoon.

Two possible mechanisms for the inhibitory effect of BoHV-1 on sperm-zona binding may be considered. The virus could cause a non-specific inhibition by binding to receptors in the vicinity of the sperm receptors (steric hindrance) or by binding to non-specific membrane receptors resulting in modulations of the membrane structure. Furthermore, BoHV-1 could inhibit sperm-zona binding in a specific manner by binding to the sperm receptors causing selective masking or conformational change of these receptors. The specificity of the virus-sperm interaction could be verified by antibodies against the sperm receptors having a comparable inhibitory effect on sperm-zona binding as BoHV-1. However, due to the unidentified nature of the bovine sperm receptors, such antibodies are not yet available.

Since carbohydrates are associated with mammalian sperm-oocyte interactions as well as with herpesvirus entry into host cells (Spear \& Longnecker 2003), it may be possible that the receptor-ligand systems of both adhesion events interfere with each other by using the same receptors. Glycan portions of BoHV-1 glycoproteins could interact specifically with sperm receptors, as a result of which the receptors lose their ability to bind to glycan portions of zona glycoproteins. Regarding this hypothesis, the gC receptor heparan sulfate is an unlikely candidate to function also as sperm receptor because this carbohydrate could not interfere with bovine IVF by inhibiting sperm penetration (Tanghe et al. 2004b). Furthermore, the 
function of $\mathrm{gC}$ as a major attachment ligand during the virus-sperm interaction suggests that BoHV-1 affects sperm-zona binding in a non-specific manner. Glycoprotein C may interact with heparin bound to heparin-binding molecules on the sperm plasma membrane during capacitation, as a result of which the sperm receptors are not functionally active any more due to steric hindrance or to modulations of the membrane structure. However, we cannot exclude a specific gC-induced inhibition of sperm-zona binding for two reasons. After primary binding to heparin on the sperm surface, gC may bind via secondary binding mechanisms to sperm receptors involved in sperm-zona binding. Alternatively, next to heparan sulfate, gC may also be able to bind to other receptors, including sperm receptors for zona glycoproteins.

Despite the fact that the results presented in this study have suggested that $\mathrm{gD}$ serves as a minor attachment ligand during the virus-sperm interaction, the mechanism of gD-sperm binding cannot be clarified due to the unidentified nature of the gD receptor. Two possible receptors for BoHV-1 gD have been described in the literature. The BoHV-1 gD receptor could be a mannose-6-phosphate receptor which can be used by HSV to enter cells (Brunetti et al. 1995). Since D-mannose has been shown to participate in bovine sperm-oocyte interactions (Amari et al. 2001, Tanghe et al. 2004a), the virus-induced inhibition of sperm-zona binding observed in this study could be partly explained by specific binding of gD to sperm D-mannose receptors involved in sperm-zona binding. Another receptor for BoHV-1 gD could be the membrane glycoprotein $\mathrm{HveC}$ which was shown to be involved in the entry of several alphaherpesviruses, including BoHV-1 (Geraghty et al. 1998, CampadelliFiume et al. 2000, Martinez \& Spear 2002). However, Connolly et al. (2001) demonstrated that the BoHV-1 glycoprotein $\mathrm{gD}$ binds directly but with low affinity to human HveC and therefore suggested that BoHV-1 infection of a natural host cell is mediated by a receptor other than a bovine HveC homolog. Moreover, Geraghty et al. (2001) found that the binding of gD to HveC is not sufficient for virus entry and that there are structural requirements for entry activity independent of gD binding.

In conclusion, the present study provided evidence that BoHV-1 can interfere with bovine IVF by inhibiting sperm-zona binding. The virus exerts this inhibitory effect by interacting with spermatozoa. The major ligand for the binding of BoHV-1 virions to a spermatozoon seems to be glycoprotein $\mathrm{gC}$, while glycoprotein $\mathrm{gD}$ may serve as a minor attachment ligand. Further research is required to determine whether or not the inhibitory effect of BoHV-1 on sperm-zona binding is due to a specific interference of the receptor-ligand system of BoHV-1 with that of the spermatozoon. Furthermore, a potential negative effect of BoHV-1 on sperm interactions with the oolemma needs to be investigated.

\section{Acknowledgements}

This research was supported by the Institute for the Promotion of Innovation by Science and Technology in Flanders (grant no. 1025) and the Fund for Scientific Research - Flanders (Belgium) (grant no. G.0297.01). The authors declare that there is no conflict of interest that would prejudice the impartiality of this scientific work.

\section{References}

Amari S, Yonezawa N, Mitsui S, Katsumata T, Hamano S, Kuwayama M, Hashimoto Y, Suzuki A, Takeda Y \& Nakano M 2001 Essential role of the nonreducing terminal $\alpha$-mannosyl residues of the $N$ linked carbohydrate chain of bovine zona pellucida glycoproteins in sperm-egg binding. Molecular Reproduction and Development $59221-226$.

Baranowski E, Keil G, Lyaku J, Rijsewijk FAM, Van Oirschot JT, Pastoret P-P \& Thiry E 1996 Structural and functional analysis of bovine herpesvirus 1 minor glycoproteins. Veterinary Microbiology 53 91-101.

Bielanski A \& Dubuc C 1994 In vitro fertilization and culture of ova from heifers infected with bovine herpesvirus-1 (BHV-1). Theriogenology 41 1211-1217.

Brunetti CR, Burke RL, Hoflack B, Ludwig T, Dingwell KS \& Johnson DC 1995 Role of mannose-6-phosphate receptors in herpes simplex virus entry into cells and cell-to-cell transmission. Journal of Virology 69 3517-3528.

Byrne KM, Horohov DW \& Kousoulas KG 1995 Glycoprotein B of bovine herpesvirus-1 binds heparin. Virology 209 230-235.

Campadelli-Fiume G, Cocchi F, Menotti L \& Lopez M 2000 The novel receptors that mediate the entry of herpes simplex viruses and animal alphaherpesviruses into cells. Reviews in Medical Virology 10 305-319.

Connolly SA, Whitbeck JJ, Rux AH, Krummenacher C, van Drunen Littel-van den Hurk S, Cohen GH \& Eisenberg RJ 2001 Glycoprotein $\mathrm{D}$ homologs in herpes simplex virus type 1 , pseudorabies virus, and bovine herpes virus type 1 bind directly to human HveC(nectin-1) with different affinities. Virology 280 7-18.

van Drunen Littel-van den Hurk S \& Babiuk LA 1985 Antigenic and immunogenic characteristics of bovine herpesvirus type-1 glycoproteins GVP 3/9 and GVP 6/11a/16, purified by immunoadsorbent chromatography. Virology 144 204-215.

van Drunen Littel-van den Hurk S, Khattar S, Tikoo SK, Babiuk LA, Baranowski E, Plainchamp D \& Thiry E 1996 Glycoprotein H (gll/gp108) and glycoprotein L form a functional complex which plays a role in penetration, but not in attachment, of bovine herpesvirus 1. Journal of General Virology 77 1515-1520.

Dubuisson J, Israel BA \& Letchworth GJ 1992 Mechanisms of bovine herpesvirus type 1 neutralization by monoclonal antibodies to glycoproteins gl, gIII and gIV. Journal of General Virology 73 $2031-2039$.

Elazhary M, Lamothe P, Silim A \& Roy A 1980 Bovine herpesvirus type 1 in the sperm of a bull from a herd with fertility problems. Canadian Veterinary Journal 21 336-339.

Engels M \& Ackermann M 1996 Pathogenesis of ruminant herpesvirus infections. Veterinary Microbiology 53 3-15.

Fuller AO \& Lee WC 1992 Herpes simplex virus type 1 entry through a cascade of virus-cell interactions requires different roles of $\mathrm{gD}$ and gH in penetration. Journal of Virology 66 5002-5012.

Geraghty RJ, Krummenacher C, Cohen GH, Eisenberg RJ \& Spear PG 1998 Entry of alphaherpesviruses mediated by poliovirus receptorrelated protein 1 and poliovirus receptor. Science 280 1618-1620.

Geraghty RJ, Fridberg A, Krummenacher C, Cohen GH, Eisenberg RJ \& Spear PG 2001 Use of chimeric nectin-1(HveC)-related receptors to demonstrate that ability to bind alphaherpesvirus gD is not necessarily sufficient for viral entry. Virology 285 366-375. 
Gordon I 1994 In vitro fertilization. In Biotechnology in Agriculture, no. 11, Laboratory production of cattle embryos, ch 4, pp 170-226. Ed. I Gordon. UK: CAB International.

Gougoulidis T, Trounson A \& Dowsing A 1999 Inhibition of bovine sperm-oocyte fusion by the carbohydrate GalNAc. Molecular Reproduction and Development 54 179-185.

Huck RA, Millar PG, Evans DH, Stables JW \& Ross A 1971 Penoposthitis associated with infectious bovine rhinotracheitis-infectious pustular vulvovaginitis (I.B.R.-I.P.V.) virus in a stud of bulls. Veterinary Record 88 292-297.

Kawakami E, Vandevoort CA, Mahi-Brown CA \& Overstreet JW 1993 Induction of acrosome reactions of canine sperm by homologous zona pellucida. Biology of Reproduction 48 841-845.

Lee WC \& Fuller AO 1993 Herpes simplex type 1 and pseudorabies virus bind to a common saturable receptor on Vero cells that is not heparan sulfate. Journal of Virology 67 5088-5097.

Li Y, van Drunen Littel-van den Hurk S, Babiuk LA \& Liang XP 1995 Characterization of cell-binding properties of bovine herpesvirus 1 glycoproteins B, C, and D: identification of a dual cell-binding function of gB. Journal of Virology 69 4758-4768.

Li Y, van Drunen Littel-van den Hurk S, Liang XP \& Babiuk LA 1997 Functional analysis of the transmembrane anchor region of bovine herpesvirus 1 glycoprotein gB. Virology 228 39-54.

Liang X, Babiuk LA, van Drunen Littel-van den Hurk S, Fitzpatrick DR \& Zamb TJ 1991 Bovine herpesvirus 1 attachment to permissive cells is mediated by its major glycoproteins gl, gIII and gIV. Journal of Virology 65 1124-1132.

Liang X, Pyne C, Li Y, Babiuk LA \& Kowalski J 1995 Delineation of the essential function of bovine herpesvirus $1 \mathrm{gD}$ : an indication for the modulatory role of gD in virus entry. Virology $207429-441$.

McClain DS \& Fuller AO 1994 Cell-specific kinetics and efficiency of herpes simplex virus type 1 entry are determined by two distinct phases of attachment. Virology 198 690-702.

Marshall RL, Rodriguez LL \& Letchworth GJ 1986 Characterization of envelope proteins of infectious bovine rhinotracheitis virus (bovine herpesvirus 1) by biochemical and immunological methods. Journal of Virology 57 745-753.

Marshall RL, Israel BA \& Letchworth GJ 1988 Monoclonal antibody analysis of bovine herpesvirus-1 glycoprotein antigenic areas relevant to natural infection. Virology $165338-347$.

Martinez WM \& Spear PG 2002 Amino acid substitutions in the V domain of nectin-1 (HveC) that impair entry activity for herpes simplex virus types 1 and 2 but not for pseudorabies virus or bovine herpesvirus 1. Journal of Virology 76 7255-7262.

Meyer G, Hanon E, Georlette D, Pastoret PP \& Thiry E 1987 Bovine herpesvirus type 1 glycoprotein $\mathrm{H}$ is essential for penetration and propagation in cell culture. Journal of General Virology $\mathbf{7 9}$ 1983-1987.

Miethke A, Keil GM, Weiland F \& Mettenleiter TC 1995 Unidirectional complementation between glycoprotein B homologues of pseudorabies virus and bovine herpesvirus 1 is determined by the carboxy-terminal part of the molecule. Journal of General Virology 76 1623-1635.

Nakamichi K, Matsumoto Y \& Otsuka H 2002 Bovine herpesvirus 1 glycoprotein $\mathrm{G}$ is necessary for maintaining cell-to-cell junctional adherence among infected cells. Virology $29422-30$.

van Oirschot JT 1995 Bovine herpesvirus 1 in semen of bulls and the risk of transmission: a brief review. Veterinary Quarterly 17 29-33.

Okazaki K, Matsuzaki T, Sugahara Y, Okada J, Hasebe M, Iwamura Y, Ohnishi M, Kanno T, Shimizu M \& Honda E et al. 1991 BHV-1 adsorption is mediated by the interaction of glycoprotein glll with heparinlike moiety on the cell surface. Virology 181 666-670.
Okazaki K, Honda E \& Kono Y 1994 Heparin-binding domain of bovid herpesvirus 1 glycoprotein glll. Archives of Virology 134 413-419.

Parrish JJ, Susko-Parrish J, Winer MA \& First NL 1988 Capacitation of bovine sperm by heparin. Biology of Reproduction 38 $1171-1180$.

Rebordosa X, Pinol J, Perez-Pons JA, Lloberas J, Naval J, SerraHartmann X, Espuna E \& Querol E 1996 Glycoprotein E of bovine herpesvirus type 1 is involved in virus transmission by direct cellto-cell spread. Virus Research 45 59-68.

Schroder C \& Keil GM 1999 Bovine herpesvirus 1 requires glycoprotein $\mathrm{H}$ for infectivity and direct spreading and glycoproteins $\mathrm{gH}(\mathrm{W} 450)$ and $\mathrm{gB}$ for glycoprotein D-independent cell-to-cell spread. Journal of General Virology 80 57-61.

Schwyzer M \& Ackermann M 1996 Molecular virology of ruminant herpesviruses. Veterinary Microbiology 53 17-29.

Spear PG \& Longnecker R 2003 Herpesvirus entry: an update. Journal of Virology 77 10179-10185.

Tanghe S, Van Soom A, Duchateau L \& de Kruif A 2004a Inhibition of bovine sperm-oocyte fusion by the $p$-aminophenyl derivative of Dmannose. Molecular Reproduction and Development 67 224-232.

Tanghe S, Van Soom A, Duchateau L, Nauwynck H \& de Kruif A 2004b Carbohydrates and glycoproteins involved in bovine fertilization in vitro. Molecular Reproduction and Development $\mathbf{6 8}$ 492-499.

Tikoo SK, Fitzpatrick DR, Babiuk LA \& Zamb TJ 1990 Molecular cloning, sequencing, and expression of functional bovine herpesvirus 1 glycoprotein gIV in transfected bovine cells. Journal of Virology $645132-5142$.

Van Engelenburg A, Maes R, van Oirschot JT \& Rijsewijk F 1993 Development of a rapid and sensitive polymerase chain reaction assay for detection of bovine herpesvirus type 1 in bovine semen. Journal of Clinical Microbiology 31 3129-3135.

Vanroose G, Nauwynck H, Van Soom A, Vanopdenbosch E \& de Kruif A 1997 Susceptibility of zona-intact and zona-free in vitro-produced bovine embryos at different stages of development to infection with bovine herpesvirus-1. Theriogenology 47 1389-1402.

Vanroose G, Nauwynck H, Van Soom A, Vanopdenbosch E \& de Kruif A 1998 Replication of cytopathic and noncytopathic bovine viral diarrhea virus in zona-free and zona-intact in vitro-produced bovine embryos and the effect on embryo quality. Biology of Reproduction 58 857-866.

Vanroose G, Nauwynck H, Van Soom A, Vanopdenbosch E \& de Kruif A 1999 Effect of bovine herpesvirus-1 or bovine diarrhea virus on development of in vitro-produced bovine embryos. Molecular Reproduction and Development 54 255-263.

Vogel FS, Flores EF, Weiblen R, Winkelmann ER, Moraes MP \& Braganca JF 2004 Intrapreputial infection of young bulls with bovine herpesvirus type 1.2 (BHV-1.2): acute balanoposthitis, latent infection and detection of viral DNA in regional neural and non-neural tissues 50 days after experimental reactivation. Veterinary Microbiology 98 185-196.

Wu SX, Zhu XP \& Letchworth GJ 1998 Bovine herpesvirus 1 glycoprotein $\mathrm{M}$ forms a disulfide-linked heterodimer with the $\mathrm{U}(\mathrm{L}) 49.5$ protein. Journal of Virology 72 3029-3036.

Yoshitake N, Xuan X \& Otsuka H 1997 Identification and characterization of bovine herpesvirus-1 glycoproteins $\mathrm{E}$ and I. Journal of General Virology 78 1399-1403.

Received 23 December 2004

First decision 18 March 2004

Accepted 6 May 2005 